\title{
ANALISIS KESIAPAN BIDAN DALAM PELAKSANAAN PELAYANAN KEBIDANAN KOMPLEMENTER
}

\author{
Jumiatun , Shinta Ayu Nani \\ Universitas Bhakti Kencana, Jl.Soekarno Hatta No.99 Kendal, (0294381299) \\ jumiatun101074@gmail.com
}

\begin{abstract}
ABSTRAK
Terapi komplementer merupakan terapi yang bertujuan untuk melengkapi pengobatan medis konvensional. Penyelenggaraan terapi komplementer telah diatur dalam Permenkes RI Nomor 1109 Tahun 2007 tentang penyelenggaraan pengobatan komplementer alternatif di fasilitas pelayanan kesehatan. Menjadi peluang bagi bidan untuk mengembangkan profesionalisme dalam pelaksanaan praktik kebidanan secara lebih komprehensif, dapat menambah nilai jual praktik kebidanan dalam memberikan pelayanan kepada masyarakat dan sebagai salah satu cara meningkatkan daya saing pasar, nilai tambah, unggulan, inovatif dan sesuai dengan harapan dari pengguna jasa layanan kebidanan. Tujuan penelitian ini untuk menganalisis faktor-faktor yang berpengaruh terhadap kesiapan bidan dalam pelaksanaan pelayanan kebidanan komplementer di IBI ranting Weleri Kabupaten Kendal. Jenis penelitian survey analitik dengan pendekatan cross sectional, sampel diambil secara proporsional sejumlah 78 bidan di IBI ranting Weleri, instrument penelitian menggunakan kuesioner. Hasil analisa data regresi sederhana menunjukkan $p$ value 0,569 (kemampuan), 0,000 (self efficacy). Tidak ada pengaruh kemampuan terhadap kesiapan dan ada pengaruh self efficacy terhadap kesiapan.
\end{abstract}

Kata kunci: kebidanan komplementer; kemampuan; kesiapan; self efficacy

\section{ANALYZE THE FACTORS THAT INFLUENCE THE READINESS OF MIDWIVES IN IMPLEMENTING COMPLEMENTARY}

\begin{abstract}
Complementary therapy is a therapy that aims to complement conventional medical treatment. Implementation of complementary therapy has been regulated in the Republic of Indonesia Minister of Health Regulation Number 1109 of 2007 concerning Implementation of Alternative Complementary Medicine in Health Service Facilities. it can be an opportunity for midwives to develop professionalism in implementing midwifery practice more comprehensively, it can also add value to midwifery practice in providing services to the community and as a way to increase market competitiveness, added value. , superior, innovative and in accordance with the expectations of users of midwifery services. The purpose of this study was to analyze the factors that influence the readiness of midwives in implementing complementary midwifery services at IBI Weleri branch, Kendal Regency. This type of analytic survey research with a cross sectional approach, the sample was taken proportionally a number of 78 midwives at IBI Weleri branch, the research instrument was used a questionnaire method. The results of simple regression data analysis showed $p$ value 0.569 (ability), 0.000 (self efficacy). There is no effect of ability on readiness, there is an effect of self-efficacy on readiness.
\end{abstract}

Key words: complementary midwifery ability; readiness; self efficacy

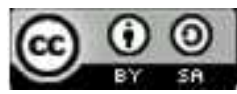




\section{LATAR BELAKANG}

Pelayanan kebidanan merupakan bagian integral dari sistem pelayanan kesehatan yang diberikan oleh bidan yang telah terdaftar, dapat dilakukan secara mandiri, kolaborasi dan rujukan (Menkes RI, 2020). Pelayanan kebidanan diberikan pada perempuan sepanjang masa reproduksinya. Bentuk intervensi dalam pelayanan kebidanan konvensional berdasarkan keilmuan dan menggunakan standar berdasarkan hasil kajian dan evidence base. Peraturan Gubernur Jawa Tengah Nomor 17 Tahun 2016 tentang penyelenggaraan kesehatan ibu dan anak di Provinsi Jawa Tengah Pasal 8 menyebutkan bahwa pertolongan persalinan normal dilakukan di fasilitas kesehatan, membentuk persepsi masyarakat bahwa bidan sudah tidak boleh praktik \& menolong persalinan.

Terapi komplementer merupakan terapi yang bersifat melengkapi dan menyempurnakan terapi konvensional, dengan tujuan untuk melengkapi pengobatan medis konvensional, bersifat rasional dan tidak bertentangan dengan hukum kesehatan di Indonesia (Rufaida, Lestari, Permata Sari, 2018). Penyelenggaraan terapi komplementer telah diatur dalam Permenkes RI Nomor 1109 Tahun 2007 tentang penyelenggaraan pengobatan komplementer alternatif di fasilitas pelayanan kesehatan. Pelayanan kebidanan komplementer merupakan bagian dari terapi komplementer dalam tatanan pelayanan kebidanan. Bidan dapat mengimplementasikan asuhan pada ibu dan anak dengan memberikan pelayanan komplementer selain pelayanan kebidanan sesuai standar dan peraturan yang berlaku.

Kepastian hukum tentang terapi komplementer tersebut menjadi peluang bagi bidan untuk mengembangkan profesionalisme dalam pelaksanaan praktik kebidanan secara lebih komprehensif, yang tentunya dengan mengedepankan ilmu kebidanan. Hal tersebut dapat menambah nilai jual praktik kebidanan dalam memberikan pelayanan kepada masyarakat. Pengembangan praktik kebidanan melalui pelayanan kebidanan komplementer dapat dilakukan dalam berbagai bentuk antara lain: post natal treatment, pijat bayi, akupresur, masase. Pelayanan kebidanan komplementer dimaknai bidan sebagai salah satu cara meningkatkan daya saing pasar, nilai tambah dan merupakan unggulan karena menyediakan pelayanan yang inovatif dan sesuai dengan harapan dari pengguna jasa layanan kebidanan (Kostania, 2015).

Penelitian yang dilakukan oleh Kostania pada Bidan Praktik Mandiri hanya 14,4\% yang melakukan pelayanan kebidanan komplementer, 50,8\% memiliki pengetahuan yang cukup dan $86,2 \%$ belum pernah mengikuti seminar atau pelatihan tentang kebidanan komplementer (Kostania, 2015). Pada penelitian ini peneliti menganalisis tentang kesiapan dalam pelaksanaan pelayanan kebidanan komplementer dengan mengambil faktor kemampuan dan self efficacy.

Praktisi kesehatan di negara berkembang sebanyak $80 \%$ lebih memilih pengobatan alternatif dibandingkan pengobatan kimia. National Center for Health Statistic Survey menganalisa dalam lima tahun terakhir terjadi peningkatan penggunaan terapi dan asuhan komplementer dari 36\% menjadi 62\% (WHO, 2012). Wawancara yang dilakukan terhadap bidan yang bekerja sebagai ASN di Puskesmas mengatakan belum siap untuk melakukan praktik komplementer meskipun sudah mengikuti pelatihan dan pendidikan. Masalah yang timbul dari uraian latar belakang tersebut yaitu faktor apa yang berpengaruh terhadap kesiapan bidan dalam pelaksanaan pelayanan kebidanan komplementer di IBI ranting Weleri kabupaten Kendal.

Tujuan penelitian ini adalah untuk menganalisis faktor-faktor yang berpengaruh terhadap kesiapan bidan dalam pelaksanaan pelayanan kebidanan komplementer di $\mid \mathrm{BI}$ ranting Weleri Kabupaten Kendal.

\section{METODE}

Jenis penelitian ini adalah survey analitik dengan pendekatan cross sectional, sampel penelitian adalah anggota IBI ranting Weleri sejumlah 78 bidan dengan kriteria belum melakukan pelayanan komplementer dengan teknik pengambilan sampel secara proporsional. Instrument pengambilan data 
menggunakan kuesioner, data hasil penelitian dianalisa menggunakan uji regresi dengan taraf signifikansi 0,05.

\section{HASIL}

Gambaran karakteristik responden pada penelitian ini meliputi umur, pendidikan, lama bekerja dan praktik bidan. Penelitian ini melibatkan 78 responden di IBI ranting Weleri Kabupaten Kendal.

\section{Tabel 1. Karakteristik Responden ( $n=78)$}

\begin{tabular}{lcc}
\hline Karakteristik & $\mathrm{n}$ & Persentase \\
\hline Umur & & \\
$21-30$ Tahun & 13 & $16,7 \%$ \\
$31-40$ Tahun & 26 & $33,3 \%$ \\
41 - 50 Tahun & 32 & $41 \%$ \\
>50 Tahun & 7 & $9 \%$ \\
\hline Pendidikan & & \\
Diploma III & 52 & $66.7 \%$ \\
Diploma IV & 18 & $23,1 \%$ \\
S1 & 8 & $10,2 \%$ \\
\hline Lama Bekerja & & \\
$1-10$ Tahun & 24 & $30,8 \%$ \\
11-20 Tahun & 20 & $25,6 \%$ \\
$21-30$ Tahun & 33 & $42,3 \%$ \\
31-40 Tahun & 1 & $1,3 \%$ \\
\hline Praktik Bidan & & \\
Praktik & 52 & $66,7 \%$ \\
Tidak Praktik & 26 & $33,3 \%$ \\
\hline
\end{tabular}

Tabel 1 menunjukkan bahwa mayoritas usia responden pada kelompok usia 41-50 tahun (41\%), mayoritas pendidikan Diploma III (52\%), lama bekerja mayoritas 21-30 tahun (42,3\%) dan mayoritas melakukan praktik kebidanan di Rumah (52\%).

Tabel 2. Hubungan Kemampuan Terhadap Kesiapan Bidan dalam Pelaksanaan Pelayanan Kebidanan Komplementer $(n=78)$

\begin{tabular}{lcccccc}
\hline \multirow{2}{*}{ Kemampuan } & \multicolumn{4}{c}{ Kesiapan } & \multicolumn{2}{c}{ Total } \\
\cline { 2 - 5 } & \multicolumn{2}{c}{ Rendah } & \multicolumn{2}{c}{ Tinggi } & \multicolumn{2}{c}{} \\
\cline { 2 - 6 } & $\mathrm{f}$ & $\%$ & $\mathrm{f}$ & $\%$ & $\mathrm{f}$ & $\%$ \\
\hline Kurang & 28 & 50,9 & 27 & 49,1 & 55 & 100 \\
Baik & 8 & 34,8 & 15 & 65,2 & 23 & 100 \\
\hline Total & 36 & 46,2 & 42 & 53,8 & 78 & 100 \\
\hline p-value $=0,193$ & & & & & & \\
\hline
\end{tabular}

Tabel 2 menunjukkan responden dengan kemampuan kurang sebagian besar memiliki kesiapan rendah dalam pelaksanaan pelayanan kebidanan komplementer (50,9\%), sedangkan responden dengan kemampuan baik sebagian besar memiliki kesiapan tinggi dalam pelaksanaan pelayanan kebidanan komplementer $(65,2 \%)$. Analisis chi-square menunjukkan $p$-value $0,193(>0,05)$.

Tabel 3. Hubungan Self Efficacy Terhadap Kesiapan Bidan Dalam Pelaksanaan Pelayanan Kebidanan Komplementer ( $n=78)$

\begin{tabular}{|c|c|c|c|c|c|c|}
\hline \multirow{3}{*}{$\begin{array}{c}\text { Self } \\
\text { Efficacy }\end{array}$} & \multicolumn{4}{|c|}{ Kesiapan } & \multirow{2}{*}{\multicolumn{2}{|c|}{ Total }} \\
\hline & \multicolumn{2}{|c|}{ Rendah } & \multicolumn{2}{|c|}{ Tinggi } & & \\
\hline & $f$ & $\%$ & $f$ & $\%$ & $f$ & $\%$ \\
\hline Rendah & 33 & 70,2 & 14 & 29,8 & 47 & 100 \\
\hline Tinggi & 3 & 9,7 & 28 & 90,3 & 31 & 100 \\
\hline Total & 36 & 46,2 & 42 & 53,8 & 78 & 100 \\
\hline$p$-val & & & & & & \\
\hline
\end{tabular}

Tabel 3 menunjukkan responden dengan self efficacy rendah sebagian besar memiliki kesiapan rendah dalam pelaksanaan pelayanan kebidanan komplementer $(70,2 \%)$, sedangkan responden dengan self efficacy tinggi sebagian besar memiliki kesiapan tinggi dalam pelaksanaan pelayanan kebidanan komplementer (90,3\%). Analisis chi-square menunjukkan $p$-value $0,000(<0,05)$.

Tabel 4. Pengaruh Kemampuan dan Self Efficacy Terhadap Kesiapan Bidan dalam Pelaksanaan Pelayanan Kebidanan Komplementer ( $\mathrm{n}=78$ )

\begin{tabular}{lcccrr}
\hline & & & \multicolumn{2}{c}{$\begin{array}{c}95.0 \% \\
\text { EXP(B) }\end{array}$} \\
\cline { 2 - 5 } & Sig & $\begin{array}{c}\text { Exp } \\
(B)\end{array}$ & Lower & Upper \\
\hline Kemampuan & 0,569 & 0,696 & 0,200 & 2,427 \\
\hline Self Efficacy & 0,000 & 21,167 & 5,493 & 81,574 \\
\hline
\end{tabular}

Tabel 4 menunjukkan variabel yang berpengaruh terhadap kesiapan bidan dalam pelaksanaan pelayanan kebidanan komplementer di IBI ranting Weleri Kabupaten 
Kendal adalah self efficacy ( $p$-value 0,000 ) dengan nilai OR 21,16.

\section{PEMBAHASAN}

Kemampuan adalah kapasitas seseorang individu unutk melakukan beragam tugas dalam suatu pekerjaan (Robbins., 2009). Setiap individu memiliki bentuk kemampuan yang berbeda, dan kemampuan individu pada dasarnya terdiri atas dua kelompok yaitu kemampuan intelektual dan kemampuan fisik. Kemampuan intelektual merupakan kemampuan yang dibutuhkan seseorang untuk melakukan berbagai aktivitas, berpikir, menalar, dan memecahkan masalah. Sedangkan kemampuan fisik adalah kemampuan yang diperlukan untuk melaksanakan tugas yang menuntut stamina, ketrampilan, kekuatan, dan karakteristik sejenis (Robbins, 2009). Pada penelitian ini mayoritas bidan memiliki kemampuan kurang (70,5\%). Kemampuan pada penelitian ini berkaitan dengan pengetahuan dan ketrampilan bidan pada pelayanan kebidanan komplementer, yang dapat diperoleh melalui seminar, pelatihan, workshop maupun kegiatan ilmiah sejenis.

Kemampuan responden mayoritas kurang dapat dilihat dari hasil analisa deskriptif kuesioner, bahwa mayoritas responden belum pernah mengikuti kegiatan ilmiah baik berupa seminar atau pelatihan. Sehingga pengetahuan dan ketrampilannya juga kurang, seperti terlihat dari jawaban responden pada keikutsertaan dalam kegiatan ilmiah, mayoritas belum pernah terpapar tentang : baby spa $(74,4 \%)$, pijat bayi (70,5\%), pijat ibu hamil $(73,1 \%)$, pijat ibu nifas $(78,2 \%)$. Hal ini tidak sesuai dengan karakteristik responden berdasarkan lama bekerja yang mayoritas lama bekerja pada kelompok 21 - 30 tahun (42,3 \%) yang seharusnya memiliki kemampuan baik berdasarkan pengalaman.

Hasil analisis disebutkan bahwa bidan yang memiliki kemampuan baik lebih siap untuk melakukan pelayanan kebidanan komplementer. Pengetahuan dan ketrampilan seorang bidan menjadi modal utama dalam pelaksanaan pelayanan kepada masyarakat, sehingga untuk siap dalam melakukan pelayanan kebidanan komplementer bidan membutuhkan kemampuan intelektual berupa pengetahuan dan kemampuan fisik berupa ketrampilan.

Self Efficacy dalam melakukan pelayanan kebidanan komplementer adalah keyakinan diri responden atas kemampuan yang dimilikinya untuk melakukan pelayanan kebidanan komplementer. Seseorang yang memiliki self efficacy tinggi tentang perilaku tertentu akan memiliki kepercayaan diri untuk melakukan perilaku tersebut. Begitu juga sebaliknya, orang dengan self efficacy rendah akan merasa sulit untuk dapat melakukan perilaku yang dimaksud. Menurut Bandura, self efficacy pada dasarnya adalah hasil dari proses kognitif berupa keputusan, keyakinan atau pengharapan tentang sejauh mana individu memperkirakan kemampuan dirinya dalam melaksanakan tugas (Ghufron, 2011).

Sesuai pendapat Bandura, pada penelitian ini bidan yang memiliki self efficacy tinggi juga memiliki kesiapan tinggi dalam pelaksanaan pelayanan kebidanan komplementer. Self Efficacy juga mempengaruhi kesiapan bidan dalam pelaksanaan pelayanan kebidanan komplementer di IBI ranting Weleri Kabupaten Kendal.

Hasil penelitian ini sejalan dengan penelitian yang dilakukan oleh Murhadi dan Kurniawati bahwa ada pengaruh efikasi diri terhadap perilaku seksual ( $p$ value 0,02 ). Begitu juga dengan penelitian Utami, Y.G.D dan Hudaniah bahwa ada hubungan antara self efficacy dengan kesiapan kerja $(p=0,000)$ dengan nilai koefisien korelasi $r=0,676$ berarti semakin tinggi self efficacy semakin tinggi pula kesiapan kerjanya. Penelitian yang dilakukan oleh Kostania pada Bidan Praktik Mandiri di Kabupaten Klaten, terdapat $14,4 \%$ bidan yang melakukan pelayanan kebidanan komplementer.

Menurut Bandura, sumber pengontrol perilaku adalah resiprokal antara lingkungan, tingkah laku dan pribadi. Self efficacy merupakan variabel pribadi yang penting, jika digabung dengan tujuan spesifik dan pemahaman tentang prestasi akan menjadi 
penentu tingkah laku mendatang. Keyakinan diri individu bukan sekedar prediksi tentang tindakan yang akan dilakukan di masa yang akan datang. Keyakinan akan kemampuannya merupakan determinan tentang bagaimana individu bertindak, pola berfikir dan reaksi emosional yang dialami dalam situasi tertentu. Self efficacy akan menentukan seberapa banyak usaha yang dilakukan individu dan seberapa lama dia akan tekun ketika menghadapi hambatan atau pengalaman yang kurang menyenangkan. Pada penelitian ini besarnya pengaruh self efficacy ditunjukkan dengan nilai $\operatorname{Exp}(B)=21,16$ yang berarti self efficacy memiliki pengaruh sebesar 21,16 terhadap kesiapan bidan dalam pelaksanaan pelayanan kebidanan komplementer di Kabupaten Kendal.

\section{KESIMPULAN DAN SARAN}

Kesiapan bidan dalam pelaksanaan pelayanan kebidanan komplementer di Kabupaten Kendal dipengaruhi oleh self efficacy. Diperlukan kegiatan ilmiah baik seminar ataupun pelatihan untuk meningkatkan pengetahuan dan ketrampilan bidan dalam kebidanan komplementer agar siap memberikan pelayanan kebidanan komplementer.

\section{REFERENSI}

Arikunto,S. (2013). Prosedur Penelitian Suatu Pendekatan Praktik. Jakarta. Rineka Cipta.

Ghufron, M.N. Rini, R. (2011). Teori-Teori Psikologi. Jogjakarta. Ar-Ruzz Media.
Kostania, G. (2015). Pelaksanaan Pelayanan Kebidanan Komplementer Pada Bidan Praktik Mandiri Di Kabupaten Klaten. Jurnal Kesehatan Gaster No. 12 Vol. $1 . \quad$ https://jurnal.aiskauniversity.ac.id/index.php/gaster/article/view/84.

Menkes RI. (2020). Kepmenkes RI Nomor HK.01.07/MENKES/320/2020 tentang Standar Profesi Bidan

Menkes RI. (2007). Peraturan Menteri Kesehatan RI Nomor 1109 Tahun 2007 tentang Penyelenggaraan Pengobatan Komplementer Alternatif di Fasilitas Pelayanan Kesehatan

Menkes RI. (2014). Peraturan Menteri Kesehatan RI Nomor 103 Tahun 2014 tentang Pelayanan Kesehatan Tradisional

Murhadi,T. Kurniawati,E. (2019). Pengaruh Faktor Efikasi Diri Terhadap Perilaku Seksual Remaja SMK Kesehatan Assyifa School Banda Aceh. Journal Of Healthcare Technology and Medicine Vol.5 No.2.http://jurnal.uui.ac.id/index.php/JHTM/article /view/440/177

Robbins, S.P. (2009). Organizational Behavior, 13th edition. New Jersey, Pearson Education. Upper Saddle River

Rufaida,Z. Lestari,S.W.P. Sari,D.P. (2018). Terapi Komplementer. Mojokerto. STIKes Majapahit.

Slameto. (2010). Belajar dan Faktor-Faktor yang Mempengaruhi. Jakarta. Rineka Cipta

Sugiyono. (2017). Statistik untuk Peneltian. Bandung. Alfabeta.

Utami,Y.G.D dan Hudania. (2013). Self Efficacy dengan Kesiapan Kerja Siswa Sekolah Menengah Kejuruan. Jurnal IImu Psikologi Terapan Vol.1 No.1. DOI: https://doi.org/10.22219/jipt.v1i1.1356

Widaryanti,R. Riska,H. (2019). Terapi Komplementer Pelayanan Kebidanan berdasarkan bukti scientific dan empiris. Yogyakarta. Deepublish. 